\title{
Evaluation of sweet potato for fuel bioethanol production: hydrolysis and fermentation
}

\author{
Claudia Lareo ${ }^{1 *}$, Mario Daniel Ferrari ${ }^{1}$, Mairan Guigou' ${ }^{1}$, Lucía Fajardo ${ }^{1}$, Valeria Larnaudie${ }^{1}$, María Belén Ramírez ${ }^{1}$ \\ and Jorge Martínez-Garreiro ${ }^{2}$
}

\begin{abstract}
The enzymatic starch hydrolysis and bioethanol production from a variety of sweet potato developed for bioenergy purposes (K 9807.1) on the basis of its high starch yields, was studied. Drying at $55^{\circ} \mathrm{C}$ and $95^{\circ} \mathrm{C}$ of sweet potato neither affected the sugar content nor the starch enzymatic hydrolysis efficiency. Simultaneous saccharification and ethanol fermentations for dry matter ratio of sweet potato to water from 1:8 to 1:2 (w/v) were studied. Fresh sweet potato and dried at $55^{\circ} \mathrm{C}$ (flour) were assayed. At ratios of 1:8, similar results for fresh sweet potato and flour in terms of ethanol concentration (38-45 g/L), fermentation time $(16 \mathrm{~h})$ and sugar conversion ( 100\%) were found. At higher dry matter content, faster full conversion were observed using flour. A higher ratio than that for fresh sweet potato (1:2.2) did not improve the final ethanol concentration (100 g/L) and yields. High ethanol yields were found for VHG (very high gravity) conditions. The sweet potato used is an attractive raw matter for fuel ethanol, since up to $4800 \mathrm{~L}$ ethanol per hectare can be obtained.
\end{abstract}

Keywords: Sweet potato; Bioethanol; Saccharomyces cerevisiae; Alcoholic fermentation; Simultaneous saccharification and fermentation (SSF)

\section{Introduction}

There is a considerable interest in developing biorenewable alternatives to substitute fossil fuels such as bioethanol as transportation fuel. Bioethanol contributes to diminish petroleum dependency, generates new development opportunities in the agricultural and agroindustrial sectors, more farm work and environmental benefits. Main feedstocks for bioethanol production are sugarcane (Brazil) and corn grain (USA). Because of the increasing demand for ethanol, alternative and nonconventional raw materials are under research (Mussatto et al. 2010).

Sweet potato (Ipomea batatas) has been considered a promising substrate for alcohol fermentation since it has a higher starch yield per unit land cultivated than grains (Duvernay et al. 2013; Lee et al. 2012; Srichuwong et al. 2009; Ziska et al. 2009). Industrial sweet potatoes are not intended for use as a food crop. They are bred to increase its starch content, significantly reducing its

\footnotetext{
* Correspondence: clareo@fing.edu.uy

${ }^{1}$ Depto. Bioingeniería, Facultad de Ingeniería, Universidad de la República, J. Herrera y Reissig 565, CP 11300 Montevideo, Uruguay

Full list of author information is available at the end of the article
}

attractiveness as a food crop when compared to other conventional food cultivars (visual aspect, color, taste). Therefore, they offer potentially greater fermentable sugar yields from a sweet potato crop for industrial conversion processes and the opportunity to increase planted acreage (even on marginal lands) beyond what is in place for food. It has been reported that some industrial sweet potatoes breeding lines developed could produce ethanol yields of 4500-6500 L/ha compared to 2800-3800 L/ha for corn (Duvernay et al. 2013; Ziska et al. 2009). Sweet potato has several agronomic characteristics that determine its wide adaptation to marginal lands such as drought resistant, high multiplication rate and low degeneration of the propagation material, short grow cycle, low illness incidence and plagues, cover rapidly the soil and therefore protect it from the erosive rains and controlling the weed problem (Cao et al. 2011; Duvernay et al. 2013; Vilaró et al. 2009). Previous transformation of the raw material into chips or flour (powder) can be done in order to facilitate its transport and/or plant conservation.

An effective ethanol production process is one where the amount of water added is minimal, since more energy will be required to remove it at the end of the 
process if the final ethanol concentration is low (Cao et al. 2011; Shen et al. 2011). High ethanol concentration can be reached if the fermentation broth contains high fermentable sugar concentration. In the case of ethanol production from root and tuber crops, it implies the use of a very high gravity (VHG) medium with high solid content and high viscosity. The high viscous nature causes several handling difficulties during processes, and may lead to incomplete hydrolysis of starch to fermentable sugars (Shanavas et al. 2011; Wang et al. 2008; Watanabe et al. 2010; Zhang et al. 2011). Some researchers have studied the addition of enzyme preparations to reduce viscosity from potato mashes such as pectinase, cellulase and hemicellulase (Srichuwong et al. 2009; Srichuwong et al. 2012), and xylanase (Zhang et al. 2010), in order to disrupt the cell-wall matrix. Also, VHG technology can show incomplete fermentation, since the yeast cells are exposed to several stresses (high concentration of dissolved solids which increases external osmotic pressure, high ethanol concentration can be toxic to the cells) (Pradeep \& Reddy 2010; Reddy \& Reddy 2006).

Fresh sweet potato contains high water content. The drying process of this material is an aspect to be studied to optimize its transport, storing and processing. The use of flour of sweet potato would allow working with higher sugar concentration during the fermentation than fresh sweet potato without the addition of water. In this case, it should be assessed the energy saving of manipulating lesser amount of material, the handling of high viscous material, the extra cost of drying and the effect of drying on the performance of the process (conversion of starch to fermentable sugars) (Moorthy 2002).

The conventional process for bioethanol production from starch-based materials includes the conversion of starch into fermentable sugars which generally takes place in two enzymatic steps: liquefaction using thermal-stable alphaamylase and saccharification by addition of amyloglucosidase (AMG). Most studies of starch hydrolysis use enzymes, temperature conditions and reaction times which have been done for grains, such corn. The starch of sweet potatoes is considered more complex than cereal starches, making it more challenging to hydrolyze into fermentable sugars. Besides, the digestibility of starch by enzymes varies among different cultivars (Duvernay et al. 2013; Moorthy 2002; Srichuwong et al. 2005). Yet there is still a need to establish a more defined biologically based approach to sweet potatoe starch conversion and evaluate the enzymes and processing conditions suitable for effective fermentable sugar production (Duvernay et al. 2013). The sweet potatoes used in this article has biomass yields of $10 \mathrm{t} / \mathrm{ha}$ (dry basis), higher value than cultivated varieties for human consumption which presented an average yield of up to $4.7 \mathrm{t} / \mathrm{ha}$ in Uruguay (http://www.mgap.gub.uy/portal/hgxpp001. aspx?7,5,659,O,S,0,MNU;E;27;8;MNU). No experimental information is available on the response of this variety of sweet potatoe to enzymatic saccharification and fermentation, including the use of high solid to liquid ratios.

The sweet potato used in this work (Ipomoea batatas K 9807.1) was identified as a sustainable crop for fuel bioethanol production based on both its favourable energy balance and the net GHG emission reduction, evaluated on a life cycle analysis conducted for local conditions in Uruguay (Carrasco-Letelier et al. 2013). It was developed as culture for bioenergy purposes on the basis of its high starch yields. This sweet potato variety had significantly reduced its attractiveness as a food crop when compared to other conventional food cultivars. The main aim was to study the two-step enzymatic hydrolysis of the sweet potato starch and the simultaneous saccharification and ethanol fermentation (SSF) of fresh and dried sweet potato (flour) by using mashes of different dry matter to water ratios. The drying effect on the integrity of starch and sugars, and their susceptibility to the hydrolysis after drying was also evaluated.

\section{Materials and methods}

\section{Raw material, enzymes and microorganism}

A sweet potato variety (Ipomoea batatas K 9807.1) was provided by INIA, Las Brujas, Canelones, Uruguay. To prepare a mash of fresh material, it was crushed into small pieces using a blender. The sweet potato flour was prepared by chipping the raw material and dried at $55^{\circ} \mathrm{C}$ until about $8 \%$ moisture content. Then it was milled to a mean particle size of $0.4 \mathrm{~mm}$. Table 1 shows the sweet potato composition. The differences in the starch and free sugars content between the fresh sweet potato and the flour were due to the high variability in the composition of the original raw feedstock material. However, the total sugars expressed as glucose equivalents were similar for the two materials: $75.0 \%$ and $77.0 \% \mathrm{w} / \mathrm{w}$ of dry matter, for fresh sweet potato and flour respectively.

The starch hydrolysis was performed using commercial enzymes: $\alpha$-amylase (Liquozyme ${ }^{\oplus} \mathrm{SC}$, Novozymes) and amyloglucosidase (AMG) (Spirizyme ${ }^{\circ}$ Fuel, Novozymes), a gift from Novozymes, Brazil. The activity of the enzymes was determined. One $\alpha$-amylase unit (AAU) was defined as the amount of enzyme required to produce $0.1 \mathrm{~g}$ of reducing sugars expressed as glucose per minute. The $\alpha$-amylase activity was $150 \mathrm{AAU} / \mathrm{mL}$, using a solution of $1 \%$ of potato starch (SIGMA) in $1 \mathrm{M}$ citrate buffer, gelatinized for 15 minutes at $90^{\circ} \mathrm{C}$, pH 5.7-5.9, and $82^{\circ} \mathrm{C}$ $86^{\circ} \mathrm{C}$. For the AMG, one AMG unit (AMGU) was defined as the amount of enzyme required to produce $0.05 \mathrm{~g}$ of reducing sugars expressed as glucose per minute. The AMG activity was $1000 \mathrm{AMGU} / \mathrm{mL}$, using a solution of $2 \%$ of maltose (SIGMA) in $1 \mathrm{M}$ citrate buffer, $\mathrm{pH} 4.0$, and $60^{\circ} \mathrm{C}$. The enzymatic activity was checked regularly. 
Table 1 Sweet potato composition

\begin{tabular}{|c|c|c|c|c|c|c|c|c|c|c|}
\hline \multirow{2}{*}{$\begin{array}{l}\text { Sweet } \\
\text { potato }\end{array}$} & \multirow{2}{*}{$\begin{array}{l}\text { Water } \\
\text { content } \\
(\%)\end{array}$} & \multicolumn{3}{|c|}{ Free sugars $(\% \mathrm{w} / \mathrm{wdb})$} & \multirow{2}{*}{$\begin{array}{c}\text { Starch } \\
(\% \mathrm{w} / \mathrm{w} \mathrm{db})\end{array}$} & \multirow{2}{*}{$\begin{array}{c}\text { Total } \\
\text { sugars in } \\
\text { glucose } \\
\text { equivalent } \\
(\% \mathrm{w} / \mathrm{w} \mathrm{db})\end{array}$} & \multirow{2}{*}{$\begin{array}{c}\text { Fiber } \\
(\% \mathrm{w} / \mathrm{w} \mathrm{db})\end{array}$} & \multirow{2}{*}{$\begin{array}{l}\text { Proteins } \\
(\% \mathrm{w} / \mathrm{w} \mathrm{db})\end{array}$} & \multirow{2}{*}{$\begin{array}{c}\text { Lipids } \\
\text { (\% w/w db) }\end{array}$} & \multirow{2}{*}{$\begin{array}{c}\text { Ash } \\
(\% \mathrm{w} / \mathrm{w} \mathrm{db})\end{array}$} \\
\hline & & Glucose & Fructose & Sucrose & & & & & & \\
\hline Fresh & $73.1 \pm 0.1$ & $2.4 \pm 2.1$ & $2.6 \pm 1.6$ & $8.0 \pm 0.4$ & $55.5 \pm 1.8$ & $75.0 \pm 6.1$ & $1.0 \pm 0.1$ & $3.5 \pm 0.8$ & $0.4 \pm 0.1$ & $4.1 \pm 0.3$ \\
\hline Flour & $7.7 \pm 0.0$ & $2.1 \pm 0.2$ & $1.6 \pm 0.1$ & $15.8 \pm 0.6$ & $51.1 \pm 3.7$ & $77.0 \pm 5.0$ & $3.0 \pm 0.3$ & $6.6 \pm 1.5$ & $1.8 \pm 0.5$ & $2.7 \pm 0.1$ \\
\hline
\end{tabular}

$\mathrm{db}$ : dry base.

Total sugar in glucose equivalent was calculated as the sum: $1.11 \times$ starch + glucose + fructose $+1.05 \times$ sucrose.

Dry commercial baking yeast, Saccharomyces cerevisiae (Fleischmann) was used for the fermentation. The inoculum was prepared by adding $28 \mathrm{~g}$ of sweet potato (dry base) in a $500 \mathrm{~mL}$ Erlenmeyer flask containing $300 \mathrm{~mL}$ of distilled water. The medium was supplemented with salts: $\left(\mathrm{NH}_{4}\right)_{2} \mathrm{SO}_{4} 0.24 \mathrm{~g} / \mathrm{L}$ and $\mathrm{MgSO}_{4} .7 \mathrm{H}_{2} \mathrm{O} 0.12 \mathrm{~g} / \mathrm{L}$. The $\mathrm{pH}$ was adjusted to 5.8 , then $5.4 \mu \mathrm{L}$ of $\alpha$-amylase per gram of dry raw matter was added. It was maintained at $86^{\circ} \mathrm{C}$ during $90 \mathrm{~min}$. The mash was cooled to $60^{\circ} \mathrm{C}$, the $\mathrm{pH}$ adjusted to 4.0 , then $5.4 \mu \mathrm{L}$ of AMG per gram of dry raw matter were added. It was kept at $60^{\circ} \mathrm{C}$ for $30 \mathrm{~min}$. The $\mathrm{pH}$ was adjusted to 4.5 , pasteurized at $100^{\circ} \mathrm{C}$ for $30 \mathrm{~min}$, and inoculated with $5 \mathrm{~g}$ dry baking yeast. The culture was incubated in an orbital shaker at $30^{\circ} \mathrm{C}$ and $150 \mathrm{rpm}$ for $12 \mathrm{~h}$.

\section{Drying assays}

Fresh sweet potato roots were cleaned and crushed into small pieces using a blender. One $\mathrm{kg}$ of the mash was dried in a tunnel dryer at operating conditions: $55^{\circ} \mathrm{C}$ or $95^{\circ} \mathrm{C}\left( \pm 3^{\circ} \mathrm{C}\right)$ and $0.5 \mathrm{~m} / \mathrm{s}$ air velocity. The dried material was milled using a laboratory disk mill DLFU (Bühler). Starch, free sugars (glucose, fructose and sucrose) and moisture content were determined before and after drying. From 3 to 6 replications of each assay were performed. Hydrolysis assays were performed using the flour obtained under the optimized experimental conditions found for fresh sweet potato and flour. $300 \mathrm{~mL}$ of sweet potato mash with a dry matter to water ratio $(\mathrm{w} / \mathrm{v})$ of 1:5 was prepared in a $500 \mathrm{~mL}$-Erlenmeyer flask, and then gelatinized at $90^{\circ} \mathrm{C}$. The $\mathrm{pH}$ was adjusted to 5.8 , then $5.4 \mu \mathrm{L}$ of $\alpha$-amylase per gram of dry raw matter was added to the mash. It was maintained at $86^{\circ} \mathrm{C}$ for 90 min under agitation. The mash was cooled to $60^{\circ} \mathrm{C}$ and the $\mathrm{pH}$ adjusted to 4.0. Then, 5.4 $\mu \mathrm{L}$ of AMG per gram of dry raw matter was added. The mash was maintained at $60^{\circ} \mathrm{C}$ for 30 min under agitation. At least three replications of each assay were performed.

\section{Gelatinization}

The gelatinization assays were performed for a dry matter to water ratio (w/v) of $1: 5$ at $90^{\circ} \mathrm{C}, 100^{\circ} \mathrm{C}$ and $121^{\circ} \mathrm{C}$ using both fresh sweet potato and flour. $300 \mathrm{~mL}$ of sweet potato mash was prepared in a $500 \mathrm{~mL}$-Erlenmeyer flask.
The $\mathrm{pH}$ was adjusted to 5.8 and the mash was kept for $15 \mathrm{~min}$ at the temperature studied. At least 2 replications of each assay were performed.

\section{Liquefaction}

The hydrolysis assays were performed for a dry matter to water ratio $(\mathrm{w} / \mathrm{v})$ of 1:5 using both fresh sweet potato and flour. Assays were performed with and without previous gelatinization. $300 \mathrm{~mL}$ of sweet potato mash was prepared in a $500 \mathrm{~mL}$-Erlenmeyer flask. The $\mathrm{pH}$ was adjusted to 5.8. The reaction started by adding $5.4 \mu \mathrm{L}$ of $\alpha-$ amylase per gram of dry raw matter. The mash was maintained at $86^{\circ} \mathrm{C}$ under agitation. The reaction was stopped with $40 \%$ trichloroacetic acid or $0.06 \mathrm{~N} \mathrm{NaOH}$ and immersion in an ice batch at different times. From 2 to 10 replications of each assay were performed.

\section{Saccharification}

After the starch liquefaction step, the sweet potato mash was cooled to $60^{\circ} \mathrm{C}$ and the $\mathrm{pH}$ adjusted to 4.0. Then, $5.4 \mu \mathrm{L}$ of AMG per gram of dry raw matter was added. The mash was maintained at $60^{\circ} \mathrm{C}$ under agitation. The reaction was stopped with $0.06 \mathrm{~N} \mathrm{NaOH}$ at different times. From 2 to 10 replications of each assay were performed.

\section{Simultaneous saccharification and fermentation (SSF)}

SSF were performed using both fresh sweet potato and flour for different dry matter to water ratios $(\mathrm{w} / \mathrm{v})$. The ratios studied were 1:2.2 (corresponding to the fresh sweet potato without addition of water), 1:5 and 1:8 for fresh sweet potato, and 1:2, 1:3, 1:5 and 1:8 for sweet potato flour. The assays for ratios of 1:5 and 1:8 were performed using $500 \mathrm{~mL}$-Erlenmeyer flasks containing $300 \mathrm{~mL}$ of sweet potato mash. Due to the high viscosity of the material, for ratios of 1:2, 1:2.2 and 1:3, the assays were conducted in $250 \mathrm{~mL}$-Erlenmeyer flasks containing $150 \mathrm{~mL}$ sweet potato mash. In this case, the whole content of the flasks was used for the analyses.

The sweet potato mash was prepared by adding the right amount of water to the material (crushed fresh sweet potato or flour) in order to prepare a given dry matter to water ratio. The $\mathrm{pH}$ was adjusted to 5.8 , then 
5.4 $\mu \mathrm{L}$ of $\alpha$-amylase per gram of dry raw matter was added to the mash. The mash was kept at $86^{\circ} \mathrm{C}$ for 90 min under agitation. It was cooled to $30^{\circ} \mathrm{C}$, the $\mathrm{pH}$ adjusted to 4.5 and pasteurized at $100^{\circ} \mathrm{C}$ for $30 \mathrm{~min}$. It was inoculated with Saccharomyces cerevisiae to an initial cell concentration of $1 \times 10^{8}$ cell $/ \mathrm{mL}$ and $5.4 \mu \mathrm{L}$ of AMG per gram of dry raw matter was added. It was incubated in an orbital shaker at $100 \mathrm{rpm}$ and $30^{\circ} \mathrm{C}$. At least 2 replications of each assay were performed.

\section{Analytical methods}

Sugars (sucrose, glucose, fructose and maltose), ethanol and glycerol concentrations were determined using a HPLC (Shimadzu, Kyoto, Japan) equipped with a Shodex SUGAR KS-801 column, or a Phenomenex Rezex RPMMonosaccharide column, and a refractive index detector (RID-10A). The total sugar content in mashes was expressed in glucose equivalents (glucose + fructose + $1.05 \times$ sucrose $+1.05 \times$ maltose). The total sugar in raw matter was expressed in glucose equivalent as the sum: $1.11 \times$ starch + glucose + fructose $+1.05 \times$ sucrose .

The reducing sugar content was determined using the DNS technique using glucose as standard (Miller 1959).

Starch content was enzymatically determined by NREL analytical procedure (Sluiter \& Sluiter 2005), proteins by Kjeldahl, lipids by Soxhlet method, fiber and ashes by AOAC methods. The moisture content was determined by drying at $60^{\circ} \mathrm{C}$. Cellular concentration was determined by counting in a Neubauer chamber. Methylene blue staining was used to discriminate live and dead cells.

The viscosity profile during gelatinization and liquefaction of sweet potato flour mashes was determined using a starch cell in a rheometer (Anton Paar Physica MCR 301).

\section{Statistical analyses}

Analyses of variance (ANOVA) of the data were performed for starch hydrolysis percentage using KaleidaGraph ${ }^{\text {tw }}$, Synergy Software. Differences between means were considered significant when $p \leq 0.05$.

\section{Results and discussion \\ Gelatinization}

The heating step generated a highly viscous paste for the three temperatures studied $\left(90^{\circ} \mathrm{C}, 100^{\circ} \mathrm{C}\right.$ and $\left.121^{\circ} \mathrm{C}\right)$. A better homogenization of the mash was observed with increasing temperature. Gelatinization would allow enzymes to penetrate easily into starch structures contributing to a more efficient reaction (Delgado et al. 2009; Hansen et al. 2008). After the gelatinization step, mean reducing sugar values of 62,69 and 54 g glucose equivalent/L for fresh sweet potato and 43, 57 and $52 \mathrm{~g}$ glucose equivalent/L for flour were found for 90,100 and $121^{\circ} \mathrm{C}$ respectively (Figure 1 ). The starch hydrolysis percentage was in the range of $47-61 \%$ and $34-45 \%$ for fresh material and flour respectively, without enzyme addition.

The reducing sugar concentration found after gelatinization without enzyme addition, was particularly high. According to the free soluble sugar content of the raw material, only 7 to $9 \mathrm{~g}$ of glucose equivalent/L should be found in the sweet potato mash. The high sugar content observed, suggests that the heat treatment produced a partial starch hydrolysis.

\section{Liquefaction}

The liquefaction step involves the partial starch hydrolysis by the addition of the $\alpha$-amylase at high temperature. High values of hydrolysis percentages were found after this process (in the range of $78 \%-80 \%$ and $61 \%-74 \%$ for fresh sweet potato and flour respectively). Figure 1 shows the sugar content after the liquefaction step.

The liquefaction was studied under the following conditions: (a) a gelatinization step was performed before the addition of the $\alpha$-amylase at $90^{\circ} \mathrm{C}$, and (b) without the gelatinization as a separate step (the enzyme was added before heating the sample to the liquefaction temperature, $\left.86^{\circ} \mathrm{C}\right)$. No significant difference $(p \leq 0.05)$ was found for the starch hydrolysis percentages and reducing sugar concentration values for the two assays performed. After $90 \mathrm{~min}$, similar values of reducing sugar concentration were found: 71 and $77 \mathrm{~g}$ of glucose equivalent /L for the two assays respectively (Figure 1).

The preparation of starchy media for VHG fermentation produces mashes having very high viscosity, which are difficult to handle. The addition of $\alpha$-amylase also reduces the starch-paste viscosity. Figure 2 shows the viscosity and temperature profiles during the gelatinization and liquefaction of the sweet potato flour mashes. These assays were performed for a dry matter to water ratio $(w / v)$ of 1:5. The gelatinization temperature was $89^{\circ} \mathrm{C}$, which corresponded to a viscosity peak of $1175 \mathrm{cP}$. Immediately after the addition of the $\alpha$-amylase the viscosity decreased from 750 to $400 \mathrm{cP}$ in few seconds. This fact demonstrated the high enzymatic activity of the $\alpha$-amylase. For simultaneous gelatinization and liquefaction process, the viscosity profile did not present a peak as in the case of previous gelatinization before the addition of the enzyme. This would indicate that gelatinization was not observed, probably due to the rapid enzymatic action. The viscosity increased gradually reaching the value of $400 \mathrm{cP}$. Although the viscosity profiles for the two assays were very different, after the addition of the enzyme the viscosity values reached were very similar.

From the results found in this study, the gelatinization step before the addition of the amylase would not be necessary. It also allows working with sweet potato mashes with lower viscosity which improves the manipulation of the material especially for VHG conditions, in particular 

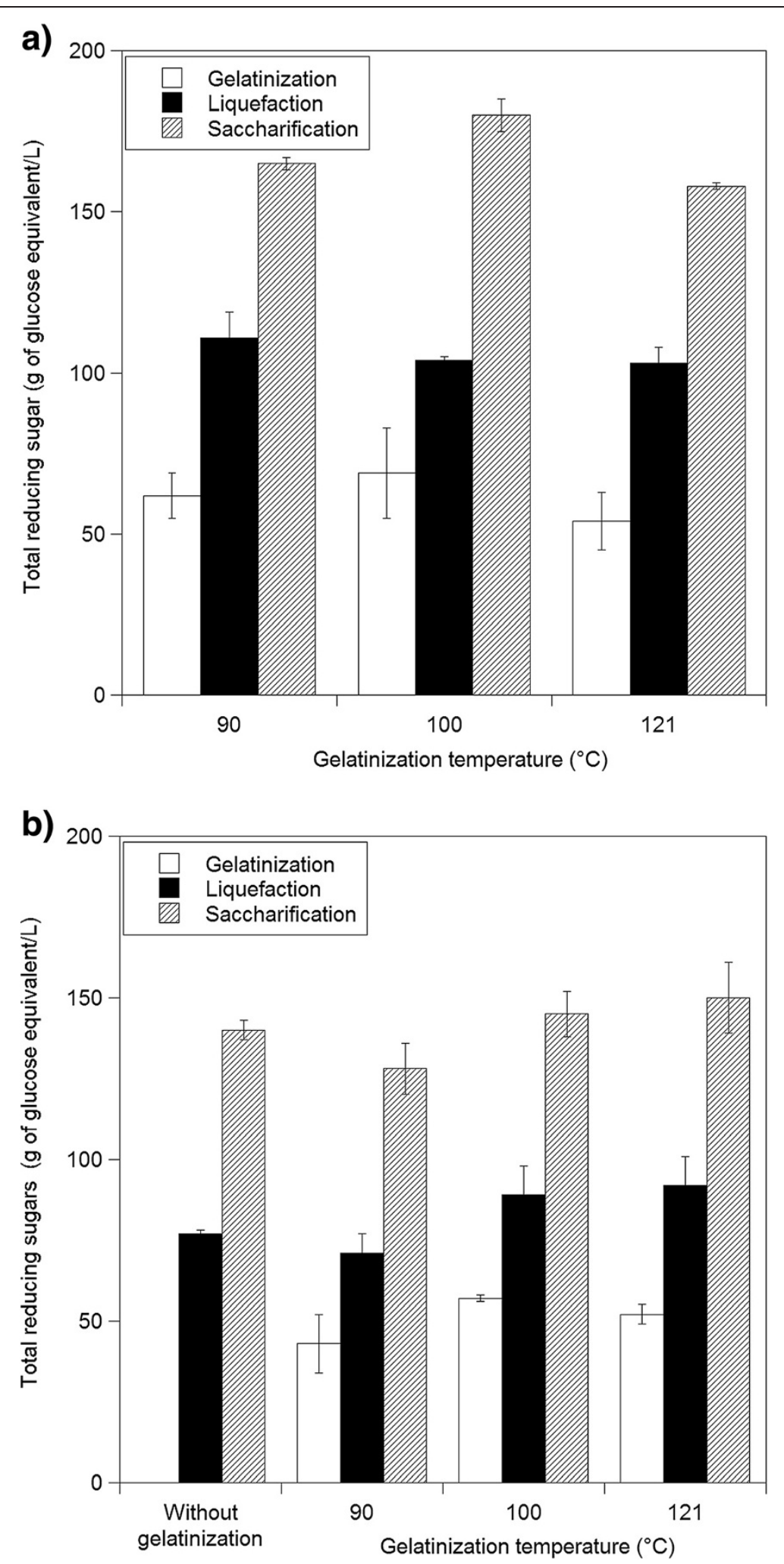

Figure 1 Reducing sugar concentration (expressed as grams of glucose equivalent/L) after the gelatinization, liquefaction and saccharification processes. a) Fresh sweet potato and b) flour. Dry matter to water ratio (w/v) of 1:5. Results are mean of 2 to 10 replications. 


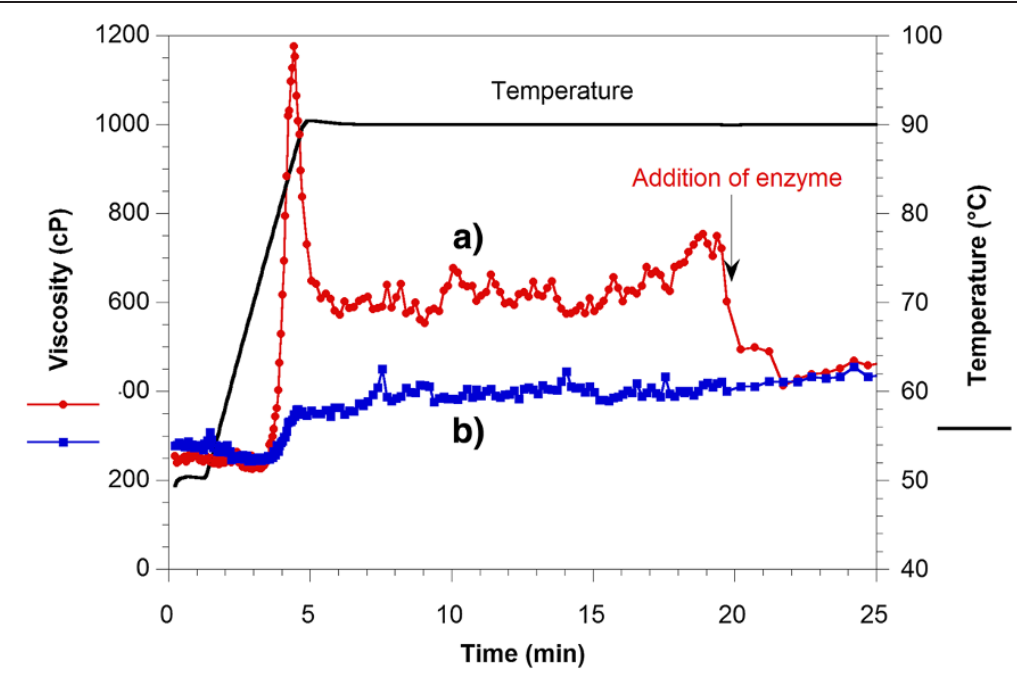

Figure 2 Viscosity and temperature profiles for sweet potato flour mashes (dry matter to water ratio (w/v) 1:5) during the liquefaction process. (a) The a-amylase was added to the sweet potato mash after gelatinization); (b) the a-amylase was added before heating. The a-amylase dose was $5.4 \mu \mathrm{L}$ per gram of dry raw matter.

its homogeneity and transport, allowing the acquisition of more consistent results and reducing the energy consumption of the process.

\section{Saccharification}

Saccharification of the sweet potato starch was assessed in assays where there was previous gelatinization to the liquefaction step and without the gelatinization step.

Figure 1 shows the final reducing sugar concentration found. For fresh sweet potato, a higher concentration was found at $100^{\circ} \mathrm{C}(165,180$ and $158 \mathrm{~g} / \mathrm{L}$ were found for mashes gelatinized at $90^{\circ} \mathrm{C}, 100^{\circ} \mathrm{C}$ and $121^{\circ} \mathrm{C}$ respectively). For sweet potato flour mashes, final average reducing sugar concentrations of 128,145 and $150 \mathrm{~g} / \mathrm{L}$ were found for mashes gelatinized at $90^{\circ} \mathrm{C}, 100^{\circ} \mathrm{C}$ and $121^{\circ} \mathrm{C}$ respectively. These values corresponded to hydrolysis percentages close to $100 \%$ for both materials (fresh sweet potato and flour). Similar results were found for cassava (Shanavas et al. 2011). The total starch hydrolysis percentages reached was similar for all temperatures assayed. An ANOVA analysis $(p \leq 0.05)$ demonstrated that there was no significant difference for the temperatures studied.

Different times have been reported for the liquefaction and saccharification steps. Some researchers add AMG while the $\alpha$-amylase is still acting (Mojović et al. 2006; Montesinos \& Navarro 2000). This fact was based on the AMG activity, which can be inhibited by the presence of carbohydrates such as glucose. In this work, it was found that $90 \mathrm{~min}$ of the $\alpha$-amylase action were sufficient to reach final starch hydrolysis percentages of $100 \%$ (after the addition of AMG).

Saccharification studies were also performed without the gelatinization step. Figure 3 shows the sugar profiles for the hydrolysis (liquefaction and saccharification steps). At 60 min of AMG action, a constant value of reducing sugar concentration was reached, which corresponded to the total starch hydrolysis. These facts permit to conclude that the gelatinization as a sole step before the addition of the enzymes was not needed to reach the complete hydrolysis.

\section{Effect of drying on sugar composition and hydrolysis}

The effect of drying of sweet potato on the sugar composition and ethanol yield was studied. Table 2 shows the sugar composition before and after drying. No statistically significant loss of starch or free sugars was found after drying for the two temperatures studied. The weight loss during these assays agreed with the experimental water loss calculated from the moisture content data.

The enzymatic hydrolysis of the flour prepared at $55^{\circ} \mathrm{C}$ and $95^{\circ} \mathrm{C}$ were determined under the optimized conditions found for the fresh sweet potato and flour (discussed in gelatinization, liquefaction and saccharification sections). For both materials, $100 \%$ of total hydrolysis was reached.

\section{Simultaneous saccharification and fermentation (SSF)}

SSF has been considered a good choice to reduce the osmotic pressure caused by high initial concentration of dissolved sugars in batch ethanol fermentation under VHG condition (Cao et al. 2011; Shen et al. 2011; Srichuwong et al. 2009; Zhang et al. 2011), and the feedback inhibition that the AMG could present by the presence of high concentrations of glucose (Cao et al. 2011; Mojović et al. 2006). In a SSF, the temperature and $\mathrm{pH}$ are more favorable for the yeast growth $\left(\sim 30^{\circ} \mathrm{C}\right)$ rather than for the AMG activity. Using this technology, the 


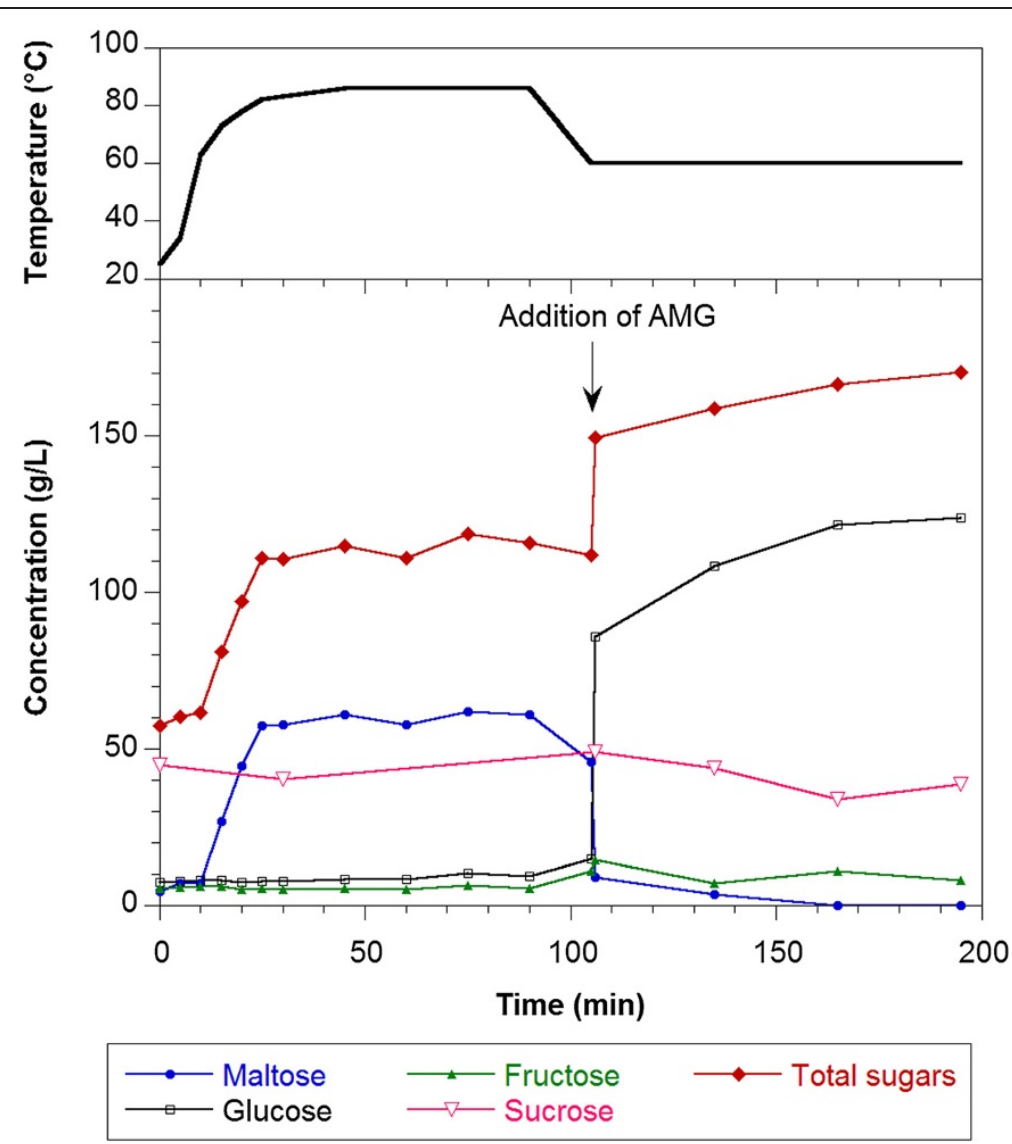

Figure 3 Sugar and temperature profiles during the hydrolysis of sweet potato flour mashes without the gelatinization step, dry matter to water ratio $(\mathbf{w} / \mathbf{v})$ of 1:5. The arrow indicates the addition of AMG. Total sugars are expressed as glucose equivalents.

time and energy of the complete process can be reduced since the saccharification step separated from fermentation at temperatures above $50^{\circ} \mathrm{C}$ is eliminated (Zhang et al. 2010). Our results confirmed that the behavior of the SSF was better than SHF for fresh sweet potato using a dry matter to water ratio $(\mathrm{w} / \mathrm{v})$ of $1: 5$, in terms of sugars, ethanol and ethanol yield (data not shown).

The use of flour of sweet potato for ethanol production was assessed in order to ferment higher sugar concentration than fresh sweet potato without the addition of water (dry matter to water ratio (w/v) 1:2.2). Different dry matter to water ratios were studied using both fresh sweet potato and flour. Table 3 presents the results obtained.

Figure 4 shows typical fermentation profiles for sweet potato flour and a dry matter to water ratio $(\mathrm{w} / \mathrm{v})$ of $1: 3$. Although it was a SSF where the temperature was lower than the optimum for the AMG, the rate of hydrolysis was higher than the rate of glucose consumption by the yeast. At $36 \mathrm{~h}$ of fermentation, the sugar conversion was

Table 2 Sweet potato composition before and after drying

\begin{tabular}{|c|c|c|c|c|c|c|c|}
\hline \multirow{2}{*}{$\begin{array}{l}\text { Drying } \\
\text { temperature } \\
\left({ }^{\circ} \mathrm{C}\right)\end{array}$} & \multirow{2}{*}{$\begin{array}{l}\text { Drying } \\
\text { time (h) }\end{array}$} & \multicolumn{3}{|c|}{ Free sugars $(\% \mathrm{w} / \mathrm{w} \mathrm{db})$} & \multirow{2}{*}{$\begin{array}{c}\text { Starch } \\
(\% \mathrm{w} / \mathrm{w} \mathrm{db})\end{array}$} & \multirow{2}{*}{$\begin{array}{l}\text { Total } \\
\text { sugars in } \\
\text { glucose } \\
\text { equivalent } \\
\text { (\% w/w } \\
\text { db) }\end{array}$} & \multirow{2}{*}{$\begin{array}{c}\text { Water } \\
\text { content } \\
\text { (\%) }\end{array}$} \\
\hline & & Glucose & Fructose & Sucrose & & & \\
\hline \multirow[t]{2}{*}{55} & 0 & $4.4 \pm 0.1$ & $2.9 \pm 0.1$ & $5.6 \pm 0.1$ & $60.4 \pm 3.9$ & $80.2 \pm 4.6$ & $68.4 \pm 0.5$ \\
\hline & 28 & $3.6 \pm 0.0$ & $3.6 \pm 0.0$ & $4.6 \pm 0.1$ & $69.0 \pm 1.4$ & $88.6 \pm 1.7$ & $8.0 \pm 1.1$ \\
\hline \multirow[t]{2}{*}{95} & 0 & $3.9 \pm 0.1$ & $3.0 \pm 0.1$ & $5.0 \pm 0.1$ & $60.7 \pm 2.1$ & $79.5 \pm 2.6$ & $65.8 \pm 1.5$ \\
\hline & 18 & $2.2 \pm 0.0$ & $3.3 \pm 0.0$ & $1.8 \pm 0.1$ & $59.7 \pm 1.2$ & $73.7 \pm 1.4$ & $7.8 \pm 0.0$ \\
\hline
\end{tabular}


Table 3 Fermentation results for fresh sweet potato and flour at different dry matter to water ratios

\begin{tabular}{|c|c|c|c|c|c|c|c|c|}
\hline $\begin{array}{l}\text { Sweet } \\
\text { potato }\end{array}$ & $\begin{array}{l}\text { Dry matter to } \\
\text { water ratio } \\
(w / v)\end{array}$ & $\begin{array}{l}\text { Ethanol } \\
(g / L)\end{array}$ & $\begin{array}{l}\text { Glycerol } \\
\text { (g/L) }\end{array}$ & $\begin{array}{c}\text { Sugar } \\
\text { conversion } \\
\left.(\%)()^{*}\right)\end{array}$ & $\begin{array}{l}\text { Efficiency } \\
(\%)(\text { (") }\end{array}$ & $\begin{array}{l}\text { Productivity } \\
\text { (g/Lh) }\end{array}$ & $\begin{array}{l}\text { Industrial yield (L ethanol/t } \\
\text { sweet potato dry base) }\left(^{+}\right)\end{array}$ & $\begin{array}{l}\text { Agroindustrial yield } \\
\left(\mathrm{L} \text { ethanol/ha) }\left(^{\#,+}\right)\right.\end{array}$ \\
\hline \multirow[t]{3}{*}{ Fresh } & $1: 2.2\left(^{\ddagger}\right)$ & $100 \pm 11$ & $9 \pm 1$ & $67 \pm 7$ & $92 \pm 1$ & $2.1 \pm 0.3$ & $320 \pm 37$ & $3170 \pm 360$ \\
\hline & $1: 5$ & $63 \pm 6$ & $8 \pm 1$ & $88 \pm 3$ & $82 \pm 4$ & $2.6 \pm 0.3$ & $380 \pm 34$ & $3730 \pm 330$ \\
\hline & $1: 8$ & $45 \pm 5$ & $8 \pm 1$ & $100 \pm 0$ & $84 \pm 9$ & $3.2 \pm 0.4$ & $490 \pm 54$ & $4790 \pm 530$ \\
\hline \multirow[t]{4}{*}{ Flour } & $1: 2$ & $99 \pm 1$ & $12 \pm 1$ & $77 \pm 2$ & $79 \pm 6$ & $2.1 \pm 0.1$ & $305 \pm 12$ & $2990 \pm 120$ \\
\hline & $1: 3$ & $97 \pm 5$ & $9 \pm 1$ & $100 \pm 0$ & $92 \pm 5$ & $2.7 \pm 0.2$ & $460 \pm 22$ & $4490 \pm 220$ \\
\hline & $1: 5$ & $58 \pm 1$ & $7 \pm 1$ & $99 \pm 2$ & $90 \pm 1$ & $3.6 \pm 0.2$ & $425 \pm 5$ & $4170 \pm 50$ \\
\hline & $1: 8$ & $38 \pm 4$ & $4 \pm 1$ & $99 \pm 0$ & $84 \pm 8$ & $2.5 \pm 0.2$ & $410 \pm 41$ & $4020 \pm 400$ \\
\hline
\end{tabular}

(") Sugar conversion based on the total sugar present in the raw material (fresh or flour)

(7) Efficiency based on $0.511 \mathrm{~g}$ ethanol $/ \mathrm{g}$ sugars as glucose.

$\left(^{\dagger}\right)$ Calculated using the ethanol density at $20^{\circ} \mathrm{C}(0.7894 \mathrm{~kg} / \mathrm{L})$.

$(\#)$ Calculated based on an agriculture yield of $10 \mathrm{t} / \mathrm{ha}$ (dry matter) (Vilaró et al. 2009) and a distillation efficiency of $98 \%$.

$\left.{ }^{\ddagger}\right)$ Fresh sweet potato without addition of water.

completed. Figure $5 \mathrm{a}$ and $5 \mathrm{~b}$ show the ethanol profiles for fresh sweet potato and flour respectively.

The ethanol concentration and the fermentation time were greater for high dry matter content (Table 3). For fresh sweet potato, the sugar consumption was completed only for the dry matter to water ratio (w/v) of 1:8 (Table 3). For ratios 1:5 and 1:2.2, the sugar concentration was constant at $34 \mathrm{~g} / \mathrm{L}$ and $107 \mathrm{~g} / \mathrm{L}$ after $24 \mathrm{~h}$ and $48 \mathrm{~h}$ respectively. The maximum ethanol concentration reached was similar to that found for flour (close to $100 \mathrm{~g} / \mathrm{L}$ ).

For sweet potato flour, the ratios 1:8, 1:5 and 1:3 showed total sugar conversion; however for the ratio 1:2, the fermentation was not completed since after $48 \mathrm{~h}$ the total residual sugars remained constant at $72 \mathrm{~g} / \mathrm{L}$ (stuck fermentation). The maximum ethanol concentration found using the baker yeast Saccharomyces cerevisiae was close to $100 \mathrm{~g} / \mathrm{L}$ (98 and $97 \mathrm{~g} / \mathrm{L}$ for dry matter to water ratio $(\mathrm{w} / \mathrm{v})$ of $1: 2$ and $1: 3$ respectively). It seems that higher ethanol concentrations than $100 \mathrm{~g} / \mathrm{L}$ were toxic for this microorganism. It has been reported that the exposure to toxic levels of ethanol is the severest of the various stresses that the yeast cells experience during fermentation, particularly under VHG conditions (Zhao \& Bai 2009). Since the ethanol tolerance was reported to

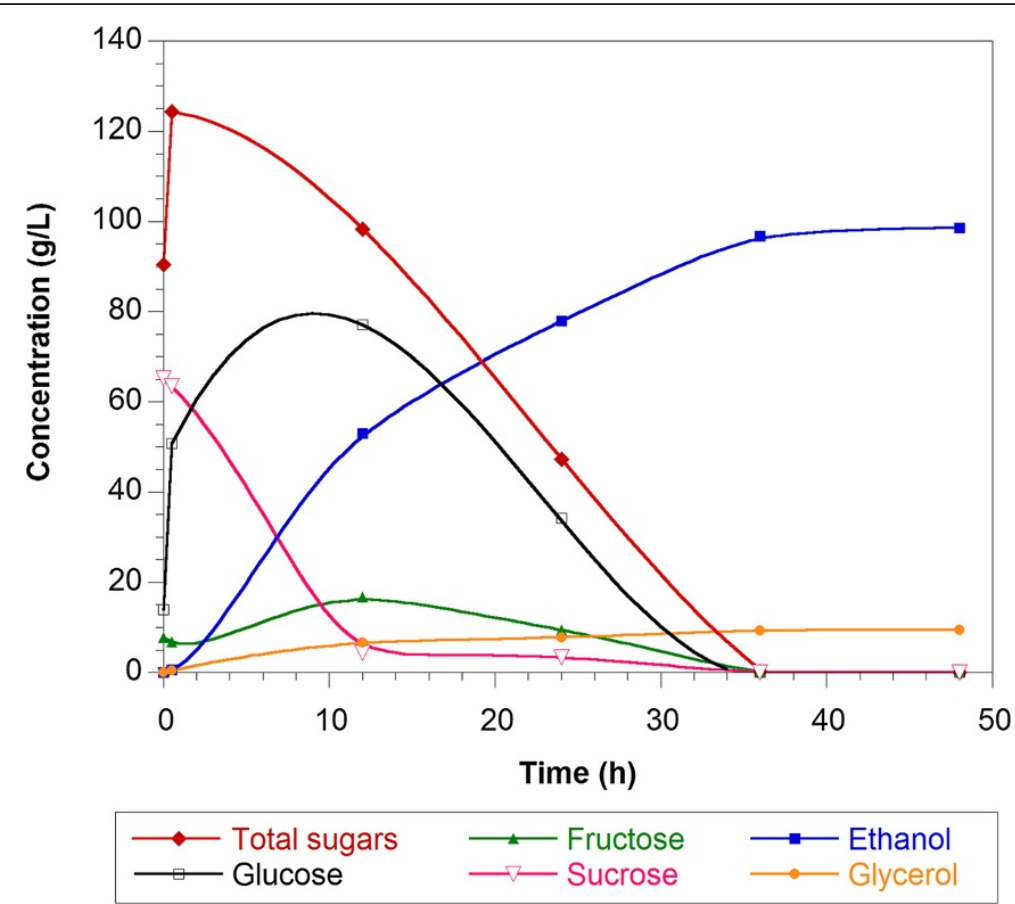

Figure 4 SSF fermentation profiles using sweet potato flour, dry matter to water ratio (w/v) 1:3. Total sugars are expressed as glucose equivalents. 

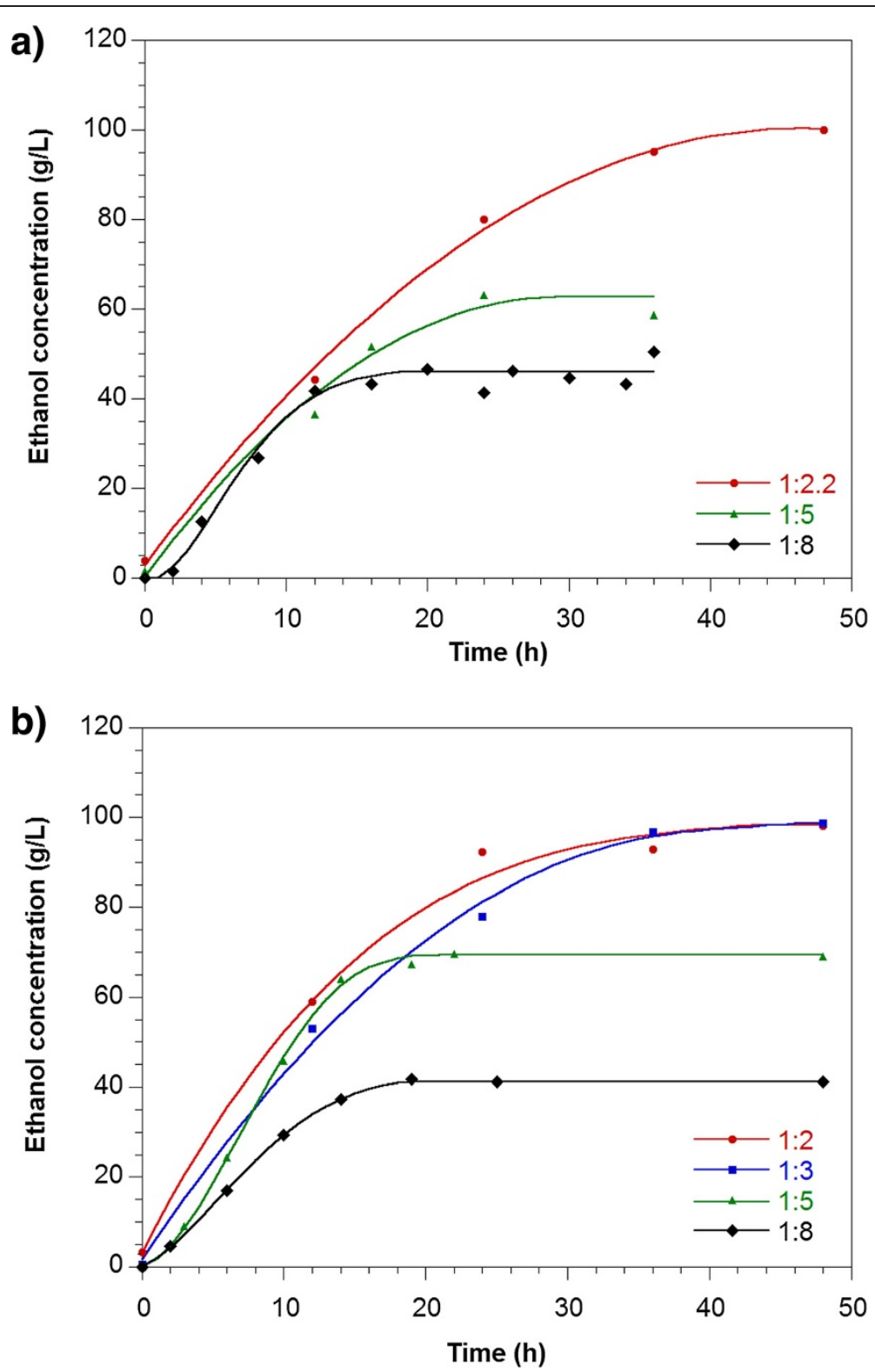

Figure 5 Ethanol profiles for SSF for (a) fresh sweet potato and (b) sweet potato flour, for different dry matter to water ratios (w/v). The ratio 1:2.2 corresponded to fresh sweet potato without addition of water.

be improved by proper supplementation of nutrients such as different sources of nitrogen, vitamins and metal ions to the media (Breisha 2010; Shen et al. 2012; Zhao \& Bai 2009), the addition of nutrients may contribute to the increase of the final ethanol concentration under VHG conditions (high dry matter to water ratios). Breisha (2010) found complete consumption of 35\% sucrose and 16\% ethanol produced for a ratio of added nitrogen to sucrose of $5 \mathrm{mg} / \mathrm{g}$ of sucrose (the nitrogen as ammonium sulphate), addition of yeast extract, thiamine and air during the first hours of fermentation. However, many of the medium supplements used in laboratory research, such as amino acids, vitamins, sterols and unsaturated fatty acids, are too expensive to be used in the industry. Thus, ethanol-tolerant yeast would be needed for efficient fermentation (Pereira et al. 2011; Watanabe et al. 2010).

The final ethanol concentration was similar for fresh sweet potato and flour at the same dry matter to water ratio. For both materials used, the concentration of glycerol was in the range 4 to $9 \mathrm{~g} / \mathrm{L}$ at the end of the fermentations. The glycerol concentration was higher for the higher dry matter to water ratios (higher solid concentration) as expected since the glycerol is produced by the cells as 
response to an osmotic stress, due to high sugar concentration (Pereira et al. 2011). The total cell concentrations were almost constant during all fermentations.

Agroindustrial yields up to $4800 \mathrm{~L} /$ ha (calculated based on ethanol produced, the real amount of sweet potato used in the experiment, crop yield (Vilaró et al. 2009) and a distillation and dehydration efficiency of 0.98) were observed. Such yields are very promising, since agroindustrial crops used for ethanol production in Uruguay, mainly sugar cane and grain sorghum, have yields of 3600 and 1800 L/ha, respectively (Carrasco-Letelier et al. 2013). Similar results were found by Jin et al. (2012).

\section{Conclusions}

Drying of sweet potato neither affected the sugar content nor the starch enzymatic hydrolysis efficiency. The dry matter content of sweet potato mashes should be carefully selected to have high yields, high final ethanol concentrations and fast fermentations. Faster full sugar conversions were observed for high dry matter content of flour mashes. Higher dry matter content than that for fresh sweet potato, did not improve the final ethanol concentration. The availability of ethanol-tolerant yeasts might improve the performance. The sweet potato used is an attractive raw matter for fuel ethanol, since up to $4800 \mathrm{~L}$ ethanol per hectare can be obtained.

\section{Competing interests}

The authors declare that they have no competing interests.

\section{Authors' contributions}

$M G, L F, V L$ and MBR conducted the experiments and data analysis; JM-G participated in the drying research plan; $C L$ and MDF developed the overall research plan, participated in the data analysis, and drafted the manuscript. All authors participated in the results discussion, and read and approved the final manuscript.

\section{Acknowledgments}

The financial support was provided by INIA-FPTA-Uruguay (Project 266). The authors would like to thank Novozymes for supplying enzymes, to Dr. Francisco Vilaró for supplying the sweet potato and his support during the project, and to Eliana Budelli for her technical assistance on viscosity determination.

\section{Author details}

${ }^{1}$ Depto. Bioingeniería, Facultad de Ingeniería, Universidad de la República, J. Herrera y Reissig 565, CP 11300 Montevideo, Uruguay. ${ }^{2}$ Depto. Operaciones Unitarias en Ingeniería Química e Ingeniería de Alimentos, Facultad de Ingeniería, Universidad de la República, J. Herrera y Reissig 565, CP 11300 Montevideo, Uruguay.

Received: 17 July 2013 Accepted: 25 September 2013 Published: 30 September 2013

\section{References}

Breisha GZ (2010) Production of 16\% ethanol from 35\% sucrose. Biomass Bioenergy 34:1243-1249

Cao Y, Tian H, Yao K, Yuan Y (2011) Simultaneous saccharification and fermentation of sweet potato powder for the production of ethanol under conditions of very high gravity. Front Chem Sci Eng 5(3):318-324

Carrasco-Letelier L, Vázquez D, D’Ottone F, Resquín F, Scoz R, Vilaró F, Rodríguez G, Vicente E, Terra J (2013) Balance energético de cadenas agro-industriales de interés para la producción de bioenergías. Revista INIA 32:46-50
Delgado R, Castro AJ, Vázquez M (2009) A kinetic assessment of the enzymatic hydrolysis of potato (Solanum tuberosum). LWT - Food Sci Technol 42:797-804

Duvernay WH, Chinn MS, Yencho GC (2013) Hydrolysis and fermentation of sweet potatoes for production of fermentable sugars and ethanol. Ind Crop Prod 42:527-537

Hansen MR, Blennow A, Pedersen S, Nørgaard L, Engelsen SB (2008) Gel texture and chain structure of amylomaltase-modified starches compared to gelatin Food Hydrocolloid 22:1551-1566

Jin Y, Fang Y, Zhang G, Zhou L, Zhao H (2012) Comparison of ethanol production performance in 10 varieties of sweet potato at different growth stages. Acta Oecol 44:33-37

Lee W-S, Chen I-C, Chang C-H, Yang S-S (2012) Bioethanol production from sweet potato by co-immobilization of saccharolytic molds and Saccharomyces cerevisiae. Renew Energy 39:216-222

Miller GL (1959) Use of dinitrosalicylic acid reagent for determination of reducing sugar. Anal Chem 31:426-428

Mojović L, Nikolić S, Rakin M, Vukasinović M (2006) Production of bioethanol from corn meal hydrolyzates. Fuel 85:1750-1755

Montesinos T, Navarro J-M (2000) Production of alcohol from raw wheat flour by amyloglucosidase and Saccharomyces cerevisiae. Enzyme Microb Technol 27:362-370

Moorthy SN (2002) Physicochemical and functional properties of tropical tuber starches: A review. Starch 54:559-592

Mussatto S, Dragone G, Guimarães P, Silva J, Carneiro L (2010) Technological trends, global market, and challenges of bio-ethanol production. Biotechnol Adv 28:817-830

Pereira FB, Guimarães PMR, Teixeira JA, Domingues L (2011) Robust industrial Saccharomyces cerevisiae strains for very high gravity bio-ethanol fermentations. J Biosci Bioeng 112(2):130-136

Pradeep P, Reddy OVS (2010) High gravity fermentation of sugarcane molasses to produce ethanol: Effect of nutrients. Indian J Microbiol 50(Suppl 1):S82-S87

Reddy LVA, Reddy OVS (2006) Rapid and enhanced production of ethanol in very high gravity $(\mathrm{VHG})$ sugar fermentation by Saccharomyces cerevisiae: Role of finger millet (Eleusine coracana L.) flour. Process Biochem 41:726-729

Shanavas S, Padmaja G, Moorthy SN, Sajeev MS, Sheriff JT (2011) Process optimization for bioethanol production from cassava starch using novel eco-friendly enzymes. Biomass Bioenergy 35:901-909

Shen Y, Zhang H, Zheng X, Zhang X, Guo J, Chen Y (2011) Very high gravity fermentation using sweet potato for fuel ethanol production. Adv Mat Res 236-238:59-62

Shen Y, Guo JS, Chen YP, Zhang HD, Zheng XX, Zhang XM, Bai FW (2012) Application of low-cost algal nitrogen source feeding in fuel ethanol production using high gravity sweet potato medium. J Biotechnol 160:229-235

Sluiter A, Sluiter J (2005) NREL Biomass Program: Determination of starch in solid biomass samples by HPLC. Biomass Analysis Technology Team, Laboratory Analytical. Procedure LAP-016. Department of Energy, United States of America

Srichuwong S, Sunarti TC, Mishima T, Isono N, Hisamatsu M (2005) Starches from different botanical sources I: Contribution of amyopectin fine structure to thermal properties and enzyme digestibility. Carbohydr Polym 60:529-538

Srichuwong S, Fujiwara M, Wang X, Seyama T, Shiroma R, Arakane M, Mukojima N, Tokuyasu K (2009) Simultaneous saccharification and fermentation (SSF) of very high gravity $(\mathrm{VHG})$ potato mash for the production of ethanol. Biomass Bioenergy 33:890-898

Srichuwong S, Orikasa T, Matsuki J, Shiina T, Kobayashi T, Tokuyasu K (2012) Sweet potato having a low temperature-gelatinizing as a promising feedstock for bioethanol production. Biomass Bioenergy 39:120-127

Vilaró F, Vicente E, Rodríguez G, Pereira G, Spina W, Reggio A, Ibañez F (2009) Nuevas variedades de boniato para usos diversos. Revista INIA 20:44-47

Wang D, Bean S, McLaren J, Seib P, Madl R, Tuinstra M, Shi Y, Lenz M, Wu X, Zhao R (2008) Grain sorghum is a viable feedstock for ethanol production. $J$ Ind Microbiol Biotechnol 35:313-320

Watanabe T, Srichuwong S, Arakane M, Tamiya S, Yoshinaga M, Watanabe I, Yamamoto M, Ando A, Tokuyasu K, Nakamura T (2010) Selection of stress-tolerant yeasts for simultaneous saccharification and fermentation (SSF) of very high gravity (VHG) potato mash to ethanol. Biores Technol 101:9710-9714

Zhang L, Chen Q, Jin Y, Xue H, Guan J, Wang Z, Zhao H (2010) Energy-saving direct ethanol production from viscosity reduction mash of sweet potato at very high gravity (VHG). Fuel Processing Technol 91:1845-1850

Zhang L, Zhao H, Gan M, Jin Y, Gao X, Chen Q, Guan J, Wang Z (2011) Application of simultaneous saccharification and fermentation (SSF) from 
viscosity reducing of raw sweet potato for bioethanol production at laboratory, pilot and industrial scales. Biores Technol 102:4573-4579

Zhao XQ, Bai FW (2009) Yeast flocculation: New story in fuel ethanol production. Biotechnol Adv 27:849-856

Ziska LH, Runion GB, Tomecek M, Prior SA, Torbet HA, Sicher R (2009) An evaluation of cassava, sweet potato and field corn as potential carbohydrate sources for bioethanol production in Alabama and Maryland. Biomass Bioenergy 33(11):1503-1508

doi:10.1186/2193-1801-2-493

Cite this article as: Lareo et al:: Evaluation of sweet potato for fuel bioethanol production: hydrolysis and fermentation. SpringerPlus 2013 2:493.

Submit your manuscript to a SpringerOpen ${ }^{\circ}$ journal and benefit from:

- Convenient online submission

- Rigorous peer review

- Immediate publication on acceptance

- Open access: articles freely available online

- High visibility within the field

- Retaining the copyright to your article 